NBER WORKING PAPER SERIES

\title{
RETIREMENT INCENTIVES AND COUPLES' RETIREMENT DECISIONS
}

\author{
Courtney C. Coile
}

Working Paper 9496

http://www.nber.org/papers/w9496

\author{
NATIONAL BUREAU OF ECONOMIC RESEARCH \\ 1050 Massachusetts Avenue \\ Cambridge, MA 02138 \\ February 2003
}

I thank Jeff Brown, Dora Costa, Peter Diamond, Leora Friedberg, Jonathan Gruber, Phillip Levine, James Poterba, and seminar participants at MIT and the NBER Summer Institute Workshop on Aging for helpful comments. Financial support from the National Institute on Aging through the National Bureau of Economic Research is gratefully acknowledged. The research reported herein was supported in part by the Center for Retirement Research at Boston College pursuant to a grant from the U.S. Social Security Administration funded as part of the Retirement Research Consortium. The opinions and conclusions herein are solely those of the author and should not be construed as representing the opinions or policy of the Social Security Administration or any agency of the Federal Government or the Center for Retirement Research at Boston College. The views expressed herein are those of the authors and not necessarily those of the National Bureau of Economic Research.

(C)2003 by Courtney C. Coile. All rights reserved. Short sections of text not to exceed two paragraphs, may be quoted without explicit permission provided that full credit including notice, is given to the source. 
Retirement Incentives and Couples' Retirement Decisions

Courtney C. Coile

NBER Working Paper No. 9496

February 2003

JEL No. H55, J26

\begin{abstract}
The typical family in the US is now a dual-earner couple, yet relatively few studies examine the retirement decision in a household context. This paper explores how husbands' and wives' retirement behavior is influenced by their own financial incentives from Social Security and private pensions and by "spillover effects" from their spouses' incentives. I find that men and women are similarly responsive to their own incentives. I further find that men are very responsive to their wives' incentives but that women are not responsive to their husbands' incentives and present evidence to suggest that this may be due to asymmetric complementarities of leisure. Policy simulations suggest that the omission of spillover effects will bias the estimated effect of changing Social Security policy on men's labor force participation.

Courtney Coile

Department of Economics

Wellesley College

106 Central Street

Wellesley, MA 02481

and NBER

ccoile@wellesley.edu
\end{abstract}




\section{Introduction}

The typical family approaching retirement today in the US is a dual-worker family. This is a recent development resulting from dramatic changes in the labor force behavior of both older men and older women during the post-war period. During this period, men shifted towards exiting the labor force at much earlier ages; for example, the labor force participation rate for men aged 55-59 dropped from $92 \%$ in 1957 to $78 \%$ in $2002 .{ }^{1}$ At the same time, factors such as changing social norms, declining fertility, and increased demand for women's labor led to large increases in the labor force participation of all women, including older women; the participation rate for women aged 55-59 rose from 38\% in 1957 to $64 \%$ in 2002 . In the Health and Retirement Study, a data set of people now reaching retirement age, nearly three-quarters of couples had both spouses in the labor force at or after age 50 .

The striking drop in male labor force participation has inspired a large literature on the effect of Social Security and pensions on men's retirement. However, two related and important issues remain vastly understudied. First, although older women are now nearly as likely to be in the labor force as older men, the effect of Social Security and pensions on women's retirement decisions is not well understood. The existing literature on this question relies on data from the 1970s, excludes private pensions, and does not draw on recent insights in the men's literature about the importance of using forward-looking incentive measures and of considering the identification of retirement incentive impacts.

A second overlooked issue in the traditional literature on retirement is the possibility that retirement incentives faced by the worker's spouse may have "spillover effects" on to the worker's own decision. Such spillover effects are likely, due both to income effects and to

\footnotetext{
${ }^{1}$ These and later statistics on labor force participation are taken from U.S. Department of Labor (1988) and the Bureau of Labor Statistics web site (data.bls.gov, series LFU604801/802/901/902).
} 
complementarity (or substitution) of leisure between the spouses, but have not been explored much in the previous literature, especially outside the context of a structural model. If spillover effects are important, the failure to estimate household models of retirement decision-making may lead to significant errors in predicting the effect of a change in Social Security policy on retirement behavior.

The purpose of this paper is to calculate the retirement incentives facing husbands and wives as a result of Social Security and private pensions and to use the incentive measures to explore these two questions. Specifically, I estimate reduced-form models of the effect of each spouse's retirement incentives on their own and their spouse's retirement decisions. This paper uses the best recent data on retirement, the Health and Retirement Study (HRS), which includes administrative data on both Social Security and private pension entitlements.

There are several key findings. First, I find that women are as responsive to their own retirement incentive measures as men; if the increment to retirement wealth resulting from additional work is raised by $\$ 1,000$, this is associated with a reduction of $0.9 \%$ of baseline retirement for men and $1.3 \%$ of baseline retirement for women. Second, I find that women's retirement incentives have important spillover effects on the husband's retirement decision that are approximately as strong as both the direct effect of her incentives on her own retirement and the direct effect of his incentives on his retirement. In contrast, the spillover effects of the husband's incentives on the wife's retirement are found to be small and statistically insignificant.

These results have several important implications. First, they demonstrate that women are strongly influenced by their own economic variables in making retirement decisions and are not merely following their husbands. Second, they suggest that the common assumption in the 
past literature that the husband's retirement decision is independent of the wife's retirement status and her other covariates is incorrect and that joint modeling of retirement decisions may be appropriate. One explanation for the finding that the wife exerts a stronger influence on the husband's retirement decision is asymmetric complementarities of leisure: husbands' enjoyment of retirement may depend much more on the wife's also being retired than vice versa. As suggestive evidence in support of this hypothesis, I show that a subset of women who would be expected to have a strong complementarity of leisure effect are similarly influenced by spillover effects as the full sample of men. Third, the results suggest that simulations of the effect of changes in Social Security policy on men's retirement may yield incorrect answers if spillover effects are ignored. I simulate two policy changes and find that the effect of the policy changes on the probability of men being in the labor force at age 65 is underestimated by $13-20 \%$ if spillover effects are omitted.

The remainder of the paper is organized as follows. Section II introduces some facts on retirement patterns, explains key features of Social Security and private pensions, and reviews the relevant literature. Section III presents the data and empirical strategy and describes the retirement incentive measures used in the paper. Section IV presents the main results, explores the asymmetric complementarities of leisure hypothesis, and presents policy simulations to measure the importance of spillover effects. Section V concludes.

\section{Background}

\section{Retirement Patterns}

Older women are important economic actors within the household. First, as illustrated in Figure 1, the labor force participation rates of older women are increasingly similar to those of 
older men, due to a major decline in men's labor force participation and an equally significant increase in women's labor force participation over the past fifty years. ${ }^{2}$ In $2002,69 \%$ of men and 55\% of women aged 55-64 were in the labor force. A decomposition of the increase in women's labor force participation indicates that married women are responsible for this trend, as the participation rate of single women has remained relatively constant. Thus the rise in female labor force participation is the rise of the dual-earner couple.

A second indicator of married women's independence as economic agents is the retirement hazard by age. For men, large spikes in the retirement hazard at ages 62 and 65 have been well documented in past work, and Social Security is thought to play a significant role in explaining the spikes. ${ }^{3}$ Figure 2 confirms the existence of these spikes for married men in the HRS and, strikingly, finds that the hazard for married women is virtually identical (the age 65 spike for women is spread out over ages 65-66, but sample sizes are small at this point). This suggests that women's retirement decisions may be influenced by the same factors that influence men's decisions, such as Social Security, and does not suggest that wives always retire with their husbands, as wives are typically several years younger.

In fact, joint retirement among spouses is a common but far from universal phenomenon. Using data from the 1970s, Hurd (1990) and Blau (1998) find that about one-third of couples in which both spouses are in the labor force at age 50 retire within one year of each other. It is difficult to replicate this calculation in the HRS, as one-third of couples had both members still in the labor force at wave 5. Nonetheless, among the couples whose retirement patterns are known, $15 \%$ of couples retired together, in $31 \%$ of cases the wife retired first, and in $54 \%$ of

\footnotetext{
${ }^{2}$ Though most analysis has focused on the post-war decline, Costa (1997) finds that the decline in men's labor force participation began in 1880. Quinn (1999) argues that the trend toward earlier retirement for men ended in the mid1980s.

${ }^{3}$ Burtless and Moffitt (1984) show that the age 62 peak did not exist prior to the introduction of benefit availability
} 
cases the husband retired first. Although joint retirement is certain to become a more significant phenomenon in the HRS in the future, as the couples still in the labor force are more likely to retire together, this tabulation demonstrates that retirement patterns are heterogeneous, with joint retirement accounting for a minority of retirement patterns.

Given the narrowed gap in older men and women's labor force participation, the similarity between men and women's retirement hazards, and the heterogeneity in retirement patterns among couples, it is clear that women are independent economic actors within the household. Therefore, it is critical to understand the process by which women make retirement decisions and the interplay between husbands' and wives' decisions.

\section{Institutional Features of Social Security and Pensions}

The institutional features of Social Security are well-known and described in more detail in Coile and Gruber (2000) and elsewhere. In the simplest terms, workers are eligible for Social Security retired worker benefits if they have forty quarters of work in covered employment. Benefits are computed by calculating the worker's average indexed monthly earnings over his best 35 years (AIME), applying a progressive formula to get the basic monthly benefit amount (Primary Insurance Amount, or PIA), then applying an actuarial adjustment to the PIA if the worker claims benefits before or after the normal retirement age (NRA, legislated to rise from 65 to 67). Benefits are first available at age 62 and are subject to an earnings test prior to the NRA. Social Security also provides dependent benefits. A worker's spouse is entitled to a benefit of $50 \%$ of the worker's PIA and a surviving spouse to $100 \%$; actuarial adjustments apply and a spouse who is dually entitled as a retired worker receives only the larger of the benefits for 
which $\mathrm{s} /$ he is eligible. Benefits are funded with a payroll tax of $12.4 \%$, paid half by employers and half by employees.

Additional work affects Social Security wealth in several ways. First, the additional year of earnings may replace an earlier zero or low earnings year in the AIME calculation, raising the benefit. Second, work beyond age 62 implies a delay in claiming benefits (if earnings are above the earnings test floor). ${ }^{4}$ Benefits are foregone for a year, but future benefits are higher due to the actuarial adjustment. Delayed claiming also raises survivor benefits (benefits are based on the worker's age at claiming) and dependent benefits (spouses are forced to delay claiming these benefits, though they may claim their own retired worker benefits if dually entitled). Finally, additional work results in additional payroll taxes. ${ }^{5}$

Private pensions may also affect retirement decisions. Pensions are a key component of retirement wealth: the Social Security Administration (2002) reports that $17 \%$ of aggregate income received by households age 65 and older is from employer-provided pensions. Defined benefit pension plans in particular offer strong incentives for work at certain ages due to plan provisions such as vesting and early and normal retirement ages. Kotlikoff and Wise (1987) find that the accrual in pension wealth at key ages such as the normal retirement age may be equal to as much as $200 \%$ of salary in some extreme cases. Thus it is critical to incorporate pensions into any analysis of retirement incentives and labor force participation.

\footnotetext{
${ }^{4}$ The earnings test now applies only until the worker has reached the NRA; however, before the year 2000, workers were subject to an earnings test until age 70. All calculations in the paper use the precise rules faced by a particular individual at the time.

${ }^{5}$ This paper treats payroll taxes as affecting the after-tax wage, rather than Social Security wealth, since it makes little sense to treat payroll taxes differently from other taxes on labor income.
} 


\section{Previous Literature}

Two strands of the retirement literature are relevant for this paper: the literature on Social Security, pensions, and men's retirement and the literature on women's and couples' retirement.

The former literature encompasses many studies and methods. The early studies estimate reduced-form models of the effect of Social Security wealth on retirement, reduced-form models incorporating the increase in wealth from working one more year or to a focal age such as 62 or 65 , and structural models of retirement using a lifetime budget constraint. ${ }^{6}$ However, this literature suffers from several problems. First, the reduced-form models are often insufficiently forward-looking, focusing on the one-year accrual in retirement wealth rather than the entire future path of accruals. Second, the identification of retirement effects in reduced-form models is suspect, as Social Security benefits are a function of past earnings and lifetime earnings are likely correlated with retirement. ${ }^{7}$ Third, many of these papers exclude private pensions and rely on now-outdated data from the 1970s, primarily the Retirement History Survey (RHS).

Subsequent papers have addressed these problems. Stock and Wise (1990a, 1990b) develop a structural "option value" model that measures the gain in utility from delaying retirement to the optimal age and find it predicts retirement well in a sample of workers from one firm. Later authors (Harris 2001, Panis et. al. 2001, Gustman and Steinmeier 2002a) structurally estimate the option value model using the HRS, though some report difficulty in getting the model to converge. Using the HRS, Coile and Gruber (2000) estimate reduced-form versions of

\footnotetext{
${ }^{6}$ For examples of these three strands of literature, see Boskin and Hurd (1978), Diamond and Hausman (1984), and Hurd and Boskin (1984); Fields and Mitchell (1982) and Hausman and Wise (1985); and Burtless and Moffitt (1984), Burtless (1986), Gustman and Steinmeier (1985). Diamond and Gruber (1998) offer a more detailed review of the literature.

${ }^{7}$ Support for this concern is found in Krueger and Pischke (1992). They use a natural experiment resulting from the phase-out of double indexation of Social Security benefits for the "notch baby" cohort and find no break in the timeseries trend toward earlier retirement by the affected cohort.
} 
the option value model and of their "peak value" model, which calculates the financial (rather than utility) gain of working to the optimal retirement age. ${ }^{8}$ They control for current and lifetime earnings in a flexible way to avoid the identification problem and find that forward-looking incentive measures have significant explanatory power for retirement, though one-year accruals do not. Despite differences among these studies, the common assumption is that a husband's retirement decision is unaffected by his wife's decision and that there are no spillover effects of the wife's retirement incentives on the husband's decision.

There is also an older literature that looks at the effect of Social Security and the husband's retirement status on married women's retirement decisions. Findings from these studies are mixed. ${ }^{9}$ However, this literature is subject to the same concerns as the early men's literature. The use of old data may be particularly problematic for women, as the behavior of today's female workers may differ substantially from that of women retiring in the 1970s. Further, though husband's retirement status is included, the assumption that it is exogenous clearly must be tested; if it is invalid, estimates from these models may be biased.

Finally, there is a small literature on couples' retirement consisting of papers that estimate structural models of family retirement. The early papers (Hurd 1990, Blau 1998, Gustman and Steinmeier 2000) rely on datasets from the 1970s and 1980s, which often lack full information on Social Security and pension entitlements, while later papers (Gustman and Steinmeier 2002b, Johnson and Favreault 2001, Maestas 2001) use the far superior HRS. These authors typically find that complementarity of leisure is much more important in explaining joint

\footnotetext{
${ }^{8}$ Samwick (1998) estimates a reduced-form option value model using the Survey of Consumer Finances, but must impute Social Security earnings histories.

${ }^{9}$ McCarty (1990) and Vistnes (1994) find evidence that women respond to the one-year Social Security wealth accrual, while Pozzebon and Mitchell (1989) find that women do not respond to the change in wealth resulting from working to age 65. Similarly, the authors have different findings regarding the effect of a retired husband on a wife's participation. See Weaver (1994) for a more detailed summary of this literature, including papers by Clark, Johnson, and McDermed (1980), Henretta and O’Rand (1980), Campione (1987), and McBride (1988).
} 
retirement than either correlation in preferences or shared household finances. These authors also find that having a retired spouse increases the probability of retirement; for example, Gustman and Steinmeier (2002b) estimate that the effect is equivalent to that of being one year older for men or three-quarters of a year older for women.

The goal of this paper is to estimate reduced-form models of the effect of each spouse's retirement incentives on their own and their spouse's retirement decisions in order to learn whether men and women respond similarly to financial incentives for retirement and whether spillover effects are significant. The paper will take advantage of insights from the recent literature on men's retirement and of the availability of excellent information on Social Security and pension entitlements in the HRS. The pros and cons of estimating reduced-form vs. structural models are well-known. Structural models require particular parameterizations of household behavior. If the chosen structure is correct, such a model is preferable in that it allows the recovery of utility parameters; however, it is generally not possible to test whether this choice is correct, and an incorrect choice will bias the results. A reduced-form analysis of couples' retirement behavior is agnostic about household behavior and is thus less ambitious but more transparent. Therefore, it will be a useful complement to the small existing literature on couples' retirement. Also, this paper will explicitly estimate the bias that results from predicting the effects of policy changes without using a household model, which has not been done in previous literature. $^{1011}$

\footnotetext{
${ }^{10}$ Blau (1998) explores the effect of raising one spouse's benefit at age 65 on the couples' labor force transitions; however, he finds that this raises the probability that both spouses work and the probability that the unaffected spouse exits while the other spouse works, so the net spillover effect is difficult to determine. Also, he uses the RHS and controls only for current benefits and benefits at age 65 , a more limited parameterization than that used here.

${ }^{11}$ A final paper worthy of mention is Baker (1999). He analyzes the 1975 introduction of the spouse's allowance in Canada for women aged 60-64 who were married to men aged 65 or older, a change that provided a strong incentive for eligible women and their husbands to retire due to means-testing of benefits. Using a differences-in-differences strategy, Baker finds that affected husbands and wives reduced their labor supply.
} 


\section{Data and Empirical Strategy}

\section{Data}

The data used in the analysis is the Health and Retirement Study (HRS). This is a survey of individuals aged 51-61 in 1992 and their spouses, with re-interviews every two years; the first five waves of the data (1992-2000) are now available. This data contains extensive information on employment, health, and family structure and can be linked to Social Security earnings histories and to pension plan data from firms for a majority of the sample, allowing for accurate calculation of retirement incentives.

The sample for the analysis is selected as follows. I begin with 4,972 married couples at wave 1 and drop 127 couples due to one spouse being born before 1922 and subject to a different set of benefit rules. Dropping couples with a missing Social Security record for either spouse lowers the sample size to 3,$233 ;^{12}$ dropping couples in which one spouse has never entered the labor force or retired prior to age 50 further lowers the sample to 1,908. Dropping observations in which either spouse reports having a pension but the HRS pension data is missing lowers the sample to 1,152 couples. ${ }^{13}$ Generating couple-year observations for all years between 1980 and 1999 in which both members of the couple are between the ages of 50 and 69 and in the labor force results in the final sample of 6,204 couple-year observations. ${ }^{14}$

The definition of retirement necessarily differs for observations before and after 1992 because of the different data available. For the earlier years, an earnings based definition is used; if earnings are positive in two consecutive years then zero, the individual is considered to have

\footnotetext{
${ }^{12}$ Haider and Solon (1999) note that Social Security records appear to be missing essentially randomly.

${ }^{13} \mathrm{I}$ am grateful to Steve Venti for allowing me to use his constructed measure of self-reported pension wealth.

${ }^{14}$ In the analysis, standard errors are corrected for repeated observations on the same couples.
} 
retired in the last year with positive earnings. ${ }^{15}$ Starting in 1992, earning reports are biannual, so the definition is based on self-reported labor status at each wave and the stated retirement date.

\section{Retirement Incentive Measures}

Social Security and pensions may affect retirement through both the level of retirement wealth and the increase in wealth resulting from future work. The wealth level effect operates through the present discounted value of retirement wealth (PDV), which is the stream of future Social Security and pension benefits the family has earned based on its work to date, discounted for mortality risk and time preference. ${ }^{16}$

The wealth accrual effect can be captured by several incentive measures. The simplest such measure is the accrual (ACC), the change in retirement wealth that results from working one additional year. However, Coile and Gruber (2001) show that the accrual of Social Security wealth is non-monotonic for many people, and it is well known that pension wealth often exhibits large spikes at particular ages. Thus there may be a small or even negative return to this year's work but a large positive return for some future year of work, and the accrual will miss this. Results with the accrual will be presented below, but it is not the preferred measure.

A second alternative is the option value measure (OV) developed by Stock and Wise (1990a,1990b). This model is based on the individual's indirect utility over work and leisure:

$$
V_{t}(R)=\sum_{s=t}^{R-1} p_{s \mid t} d^{s-t}\left(y_{s}\right)^{g}+\sum_{s=R}^{T} p_{s \mid t} d^{s-t}\left[k * B_{s}(r)\right]^{g}
$$

\footnotetext{
${ }^{15}$ This definition is applied only to years after age 50. Although Ruhm (1990) estimates that one-quarter of household heads reenter the labor force after initially retiring, such behavior is outside the scope of this analysis. ${ }^{16}$ Benefits are discounted using a $6 \%$ real discount rate and the age and sex specific U.S. life tables from the SSA Trustees Report (1995), intermediate assumption. The calculation accounts for the joint survival probabilities of both spouses and for the benefits received by the couple in each state (with appropriate actuarial adjustment). A 6\% discount rate is chosen because Coile et. al. (2002) show that this would make it optimal to claim Social Security benefits immediately upon retirement, which is what nearly all workers do.
} 
where $\mathrm{R}$ is the retirement date, $\mathrm{d}$ is the discount factor, $\mathrm{p}$ is the probability of being alive at some future date conditional on being alive today, $\mathrm{y}$ is income while working, $\mathrm{B}$ is retirement benefits, gamma is a parameter of risk aversion, $\mathrm{k}$ is a parameter to account for the disutility of labor $(\mathrm{k}>=1)$, and $\mathrm{T}$ is maximum life length. The OV measure calculates the utility gain from working to the optimal future retirement date relative to retiring today. A reduced-form version of the option value model is employed here. ${ }^{17}$

A third possible measure is peak value (PV), which is equal to the PDV of retirement wealth at its maximum value minus the PDV today. This is similar to accrual, except it is the accrual to the year in which PDV is maximized rather than the one-year accrual; if PDV has already reached its maximum, $\mathrm{PV}$ is equal to the accrual. This can be thought of as a financial version of the option value measure (utility parameters are set to one), except that it does not incorporate wages. The effects of both PV and OV on retirement will be examined below.

In order to calculate each spouse's incentive measures, one must make an assumption about the retirement behavior of the other spouse, as Social Security benefits depend on both spouses' entire earnings histories. I calculate each spouse's incentive to work conditional on the other spouse retiring at age 62 . This seems plausible, given that the median retirement age in my sample is 62 for both men and women. I have also calculated the incentive measures assuming the spouse retires at age 60 or 65 and the results using those measures are very similar.

\footnotetext{
${ }^{17}$ The assumed utility parameters are $\mathrm{K}=1.5$, gamma $=0.75$, and a real discount rate of $6 \%$; re-estimating the model with different parameters suggests that the log-likelihood is quite flat with respect to parameter choice. For both OV and PV calculations, real earnings are projected to grow at about $1 \%$, matching assumptions made by the SSA Board of Trustees (1995), Table II. Ruhm (1990) notes that retirement often includes a post-career bridge job with lower earnings; however, the calculations treat continued employment at the same job as the relevant alternative to retirement, as it is impossible to know what other options might be available to each worker. I am grateful to Dean Karlan for assistance in writing the program that calculates the worker's PIA at all future retirement dates.
} 


\section{Empirical Strategy}

The goal is to estimate the direct impact of each spouse's incentive variables on their own retirement decision and the spillover effect of own incentive variables on the spouse's retirement decision. I thus estimate equations of the following form:

$$
\begin{aligned}
\text { RET }_{\mathrm{ht}} & =\mathrm{b}_{0}+\mathrm{b}_{1} \mathrm{PDV}_{\mathrm{ct}}+\mathrm{b}_{2} \mathrm{IM}_{\mathrm{ht}}+\mathrm{b}_{3} \mathrm{X}_{\mathrm{ht}}+\mathrm{b}_{4} \mathrm{AGE}_{\mathrm{ht}}+\mathrm{b}_{5} \mathrm{EARN}_{\mathrm{ht}}+\mathrm{b}_{6} \mathrm{AIME}_{\mathrm{ht}} \\
& +\mathrm{b}_{7} \mathrm{IM}_{\mathrm{wt}}+\mathrm{b}_{8} \mathrm{X}_{\mathrm{wt}}+\mathrm{b}_{9} \mathrm{AGE}_{\mathrm{wt}}+\mathrm{b}_{10} \mathrm{EARN}_{\mathrm{wt}}+\mathrm{b}_{11} \mathrm{AIME}_{\mathrm{wt}}+\mathrm{b}_{12} \mathrm{REG}_{\mathrm{c}}+\mathrm{b}_{13} \mathrm{Y}_{\mathrm{t}}+\mathrm{e}_{\mathrm{h}}
\end{aligned}
$$

where $\mathrm{h}$ denotes the husband, w the wife, and $\mathrm{c}$ the couple; RET is a dummy indicating if the worker retires this year; PDV is retirement wealth and IM is the retirement incentive measure (ACC, $\mathrm{PV}$, or $\mathrm{OV}){ }^{18} \mathrm{AGE}$ is a set of age dummies, EARN is potential earnings next year, AIME is lifetime earnings, $\mathrm{X}$ is individual characteristics (race, education, industry and occupation, experience and its square, job tenure and its square, age difference with spouse), $\mathrm{Y}$ is year dummies, and REG is region dummies. Symmetric equations are estimated with the wife's retirement as the dependent variable. The equations are estimated as probits.

It is useful to consider the source of identification of the effect of incentive variables on retirement. Retirement incentives vary across people due to many factors, including: own age, birth cohort (due to changing mortality and Social Security rules), AIME, and next year's earnings (relative to past lowest); spouse's age, birth cohort, AIME, and earnings; interactions of the above and non-linearities in the Social Security benefit formula; and eligibility for a pension, provisions of the firm's pension plan (normal retirement age, etc.), and own work history as it affects the pension (hire date, etc.).

It is important to control for those factors that likely have an independent influence on retirement. For example, as Social Security benefits are a non-linear function of AIME,

\footnotetext{
${ }^{18} \mathrm{PDV}_{\mathrm{t}}$ is calculated for each person assuming that he or she retires at $\mathrm{t}$ and that the spouse retires at age 62 , thus the husband and the wife have slightly different PDVs (corr=0.97). For the analysis, the simple average is used.
} 
estimates that fail to control for AIME may pick up a spurious effect, such as a propensity of higher earners to retire later because they enjoy their work more. This analysis adopts a control function approach and controls in a very rich way for the factors that may influence retirement to address any possible spurious effects. The richest specification includes age dummies for both spouses, full interactions of the age dummies, a quartic in earnings and AIME for both spouses, and interactions of the earnings and AIME quartics of both spouses. ${ }^{19}$

Summary statistics are shown in Table 1. The mean annual retirement rate in the sample is $4.7 \%$ for men and $4.1 \%$ for women and the average age in the sample is 57.1 for men and 54.6 for women. The average annual accrual of retirement wealth is $\$ 1,698$ for men and $\$ 1,279$ for women, and the average peak value is $\$ 14,766$ for men and $\$ 11,541$ for women. ${ }^{20}$ However, there is substantial heterogeneity in all these figures, as is evident from the large standard deviations. The PDV of Social Security and pension wealth for an average couple is $\$ 230,651$. Option value is measured in utility units, so it is not directly comparable to the other measures.

\section{Results}

\section{Effects of Own Incentive Variables}

Tables 2 and 3 show the key coefficients from the probit models. Results are shown for the three incentive measures (ACC, PV, and OV) and for three sets of covariates: 1) demographic variables only, 2) adding quartics in earnings and AIME, and 3) adding interactions between the age dummies of husbands and wives, the earnings quartics of husbands and wives, and the AIME quartics of husbands and wives. These rich specifications should control for the

\footnotetext{
${ }^{19}$ As OV directly incorporates earnings, earnings explain a large fraction of the variation in the OV: for men, age dummies and a quartic in earnings explain $72 \%$ of the variation in OV and only $15 \%$ of the variation in PV.

${ }^{20}$ Figures are in $\$ 1992$. Obviously, the magnitude of the accrual, peak value, and PDV figures is highly dependent on the discount rate chosen.
} 
variation in the incentive measures resulting from current and past earnings, which may not be a valid source of identification for retirement effects.

The first three rows of Table 2 show the effect of the husband's incentive measures on his retirement. The accrual coefficients are negative but not statistically significant; this lack of significance is not particularly surprising, as the accrual does not capture the option value that work this year provides by enabling work in future years when there may be larger accruals. By contrast, the PV coefficients are negative and highly significant for all sets of control variables. In the preferred specification (with demographics and quartics in current and lifetime earnings), an increase in PV of $\$ 1,000$ is associated with a decrease in the husband's probability of retirement of $0.040 \%$, or $0.9 \%$ of baseline retirement; the results are not significantly different in the other specifications. The OV coefficients, though not directly comparable to the PV coefficients, are also negative and statistically significant. Thus men respond to their forwardlooking incentive measures from Social Security and pensions as expected, but the magnitude of the effects is relatively modest.

The response of women to their incentive measures is quite similar, as shown in the first three rows of Table 3. In the preferred specification, a $\$ 1,000$ increase in the wife's PV decreases her retirement probability by $0.054 \%$, or $1.3 \%$ of baseline retirement. As for men, using forward-looking incentive measures is important: the effect of accrual is negative but insignificant, while OV has a consistently negative and significant effect.

The last row in Tables 2 and 3 shows the effect of the PDV on retirement. As expected, higher wealth is associated with an increased probability of retirement. The effect is very similar for men and women and is quite significant except in the OV specifications for men. In the preferred PV specification, a $\$ 10,000$ increase in PDV raises the probability of men's retirement 
by $0.047 \%$, or $1.0 \%$ of baseline retirement and raises the probability of women's retirement by $0.049 \%$, or $1.2 \%$ of baseline retirement. ${ }^{21}$

\section{Effect of Spouse's Incentive Variables}

The spillover effect of each spouse's incentives on the other's retirement is explored in the middle three rows of Tables 2 and 3. In theory, the spillover effect could be positive or negative, as there are income and complementarity of leisure effects that work in opposite directions: if one spouse can increase the couple's retirement wealth by staying in the labor force, the other spouse may consume some of the additional wealth in the form of leisure and retire earlier, or may retire later if the value of leisure is diminished. ${ }^{22}$

As shown in Table 2, the spillover effect of the wife's incentive on the husband's retirement is negative, so the complementarity of leisure effect dominates the income effect; this effect is highly significant and is similar in magnitude to the direct effect of the husband's incentives on his retirement. In the preferred specification, a $\$ 1,000$ increase in the wife's PV leads to a $0.038 \%$ decrease in his probability of retirement, or $0.8 \%$ of baseline; the OV results are similar. ${ }^{23}$ This suggests that the past literature on men's retirement may be omitting an important variable by neglecting the wife's retirement incentive variables.

The middle three rows in Table 3 show the spillover effect of the husband's incentive variables on the wife's retirement. Strikingly, these coefficients are small, mostly positive, and never statistically significant, suggesting that women do not respond to their husbands'

\footnotetext{
${ }^{21} \mathrm{~A}$ full set of results including all covariates is available from the author upon request. In probit models including variables for health status and health insurance (not shown here), retirement incentive measures have very similar effects to those discussed here and health variables generally have the expected effects.

${ }^{22}$ Substitution of leisure is also possible; for example, if spouses perform both market and non-market labor, an increase in the return to market work for one spouse may encourage the other spouse to shift towards non-market labor. However, the previous literature suggests that complementarity of leisure is more likely.

${ }^{23}$ For accrual, the spillover effect is greater than the effect of the husband's incentives on his retirement and
} 
retirement incentives from Social Security and pensions. The finding that men respond to their wives' incentives but women do not respond to their husbands' incentives is the exact opposite of the assumption made in the traditional retirement literature, and merits further analysis. ${ }^{2425}$

One possible explanation for this finding is that there are asymmetries in the complementarity of leisure effect: husbands' enjoyment of retirement may depend much more on the wife's also being retired than vice versa. This might be the case if, for example, wives are able to busy themselves with volunteer work, grandchildren, or housework if the husband works, but husbands are less able to occupy themselves with hobbies if the wife works and dread being expected to help out more with housework. For wives, a weak complementarity of leisure effect and the income effect may roughly cancel out, leading to no overall response to husbands' incentives. For husbands, a strong complementarity of leisure effect may outweigh the income effect, so that a large financial incentive for the wife to keep working encourages both spouses to stay in the labor force. ${ }^{26}$

One way to explore the asymmetric complementarities of leisure hypothesis is to examine whether there are differences in men's and women's answers to questions about how they think about retirement and time with their spouses. Table 4 displays the answers given in 1992 for the subset of the sample in which neither spouse had previously retired. By a slight margin, husbands are more likely to report that they enjoy time with their wives on all relevant questions.

\footnotetext{
significant; however, accrual is not the preferred incentive measure for the analysis.

${ }^{24}$ Desmet et. al. (2002) reproduce the analysis presented here in the context of Belgium and find that women respond to their husbands' incentive variables but not vice versa.

${ }^{25}$ Several specification checks suggest that the strong spillover effect on the husband's decision is not the result of a non-linear effect of own incentives being picked up by the spillover coefficient. First, the correlation between spouses' incentive variables is very low, less than 0.15 for all three incentive variables. Second, the effect of the husband's incentive variable on his retirement is very similar when the wife's incentive variable is omitted from the model. Third, adding a quartic in the husband's incentive variable to his retirement regression does not affect the coefficient on the wife's incentive variable.

${ }^{26}$ The sociology literature provides some support for this explanation. In a study of married couples in NY, Moen et. al (2001) find that newly retired men whose wives continued to work were the least happy retirees and that returning to work was the best solution for these men; for newly retired women, having a "happy marriage" was a
} 
Specifically, men are more likely to say that they find time with their spouse extremely enjoyable ( $33 \%$ to $27 \%$ ), that they like to spend time doing things together with their spouse ( $52 \%$ to $49 \%$ ), that they agree or strongly agree that they look forward to retirement only if they can retire at the same time as their spouse ( $62 \%$ to $60 \%$ ), and that they think having more time with their spouse in retirement is very important ( $61 \%$ to $60 \%)$. The data also indicate that women may have more options for retirement activities, as they are more likely than their husbands to say that spending more time with children ( 42 to $33 \%$ ) or on volunteer work (17 to $13 \%$ ) is very important and equally likely to say that spending more time on hobbies or sports or having the chance to travel is very important. While there is some suggestion in the data that men's enjoyment of their leisure may depend more on the presence of the spouse than vice versa, the differences between men and women's answers to these questions are in fact fairly small.

A more direct way to examine whether complementarity of leisure affects behavior is to see whether the response to the spouse's incentive variables differs for those who report a strong complementarity of leisure time with their spouse vs. those who do not. As no single question perfectly captures complementarity of leisure, the dummy variable is defined in three different ways based on the first three questions in Table $9 .{ }^{27}$ The dummy variable is interacted with the spouse's incentive variable, with the expectation that the interacted spillover effect will be negative, as the complementarity of leisure effect will likely outweigh the income effect for this group. The sample for this analysis excludes couples in which one spouse retired prior to 1992, since the retirement expectation questions are first available in 1992.

more important factor than having a retired husband in determining retirement satisfaction.

${ }^{27}$ The three questions are: a) is time spent together with spouse extremely enjoyable; b) do you like to spend time doing things together with spouse; c) do you agree/strongly agree that you look forward to retirement only if spouse can retire too. (Note: $\mathrm{c}$ is defined as agree or strongly agree because the strongly agree group is extremely small). 
The results of this analysis for peak value are presented in Table 5. In the wife's retirement model, interacting the complementarity of leisure dummy with the husband's incentive measure has the expected outcome: the overall spillover effect is negative and significant for this group, indicating that the complementarity of leisure effect outweighs the income effect for them. For this group of women, the magnitude of the spillover effect is similar to that found for the full sample of men in 2. By contrast, the spillover effect for the other group is now always positive, reflecting the dominance of the income effect, and significant in the case of definition 2. The coefficients on own incentive measure weaken in sign and significance for some of the specifications, while PDV remains positive and significant.

The lower panel of Table 5 repeats this exercise for the husband's retirement models. Here, the effect of interacting the complementarity of leisure dummy with the wife's incentive measures is less dramatic. Prior to introducing the interactions, the coefficient on the wife's PV is negative and significant. The coefficient on the interacted PV is a larger negative number, as we would expect, while the coefficient on the non-interacted PV remains negative but is smaller and no longer significant, suggesting that the complementarity of leisure effect may more than offset the income effect even in this group.

To summarize, the above provides some suggestive evidence that asymmetric complementarities of leisure may explain the spillover results from Tables 2 and 3. First, men are slightly more likely to report enjoying time with their spouse and appear to have fewer retirement activities planned. Second, the subset of women who are categorized as having strong complementarity of leisure are found to have a similar response to their spouses' incentive variables as the full sample of men, while both subsets of men appear to have a strong

The three dummies are equal to 1 if: 1 ) a and $b$ are true; 2) a and $c$ are true; 3) a, b, and $c$ are true. Results are similar if the dummy is based on a or $\mathrm{b}$ alone, but less significant if based on $\mathrm{c}$ alone. 
complementarity of leisure effect. ${ }^{28}$ This suggests that a stronger complementarity of leisure effect for men may explain the greater importance of spillover effects for men's decisions.

\section{Policy Simulations}

The omission of spillover effects from the retirement model may lead to an incorrect estimate of the effect of a change in Social Security policy on retirement. Specifically, if a policy change alters the retirement incentives of both spouses and if the wife's incentives affect the husband's decision, then neglecting to include this spillover effect will bias the estimated effect of the policy change on men's retirement behavior. In this section, I calculate the difference in the predicted effect of a policy change when spillover effects are included.

I simulate two changes in Social Security policy: an immediate increase in the normal retirement age (NRA) to 67 and an immediate increase in the delayed retirement credit (DRC) to $8 \% .{ }^{29}$ The expected effects of the policy changes on the incentive variables and on retirement are as follows. Raising the NRA lowers PDV and has different effects on the return to work depending on the age of the worker through changes in the actuarial adjustment, so the net effect on retirement is ambiguous. ${ }^{30}$ In the sample, implementing this policy lowers mean PDV by about $\$ 11,500$ and lowers mean husband's PV by about $\$ 900$ and mean wife's PV by about \$400. Raising the DRC to $8 \%$ raises PDV for those already working past age 65 and raises the incentives for those under 65 to keep working until 65 , so the net effect on retirement is also ambiguous. In the sample, implementing this policy raises mean PDV by $\$ 250$ and raises mean husband's PV by over $\$ 900$ and wife's PV by over $\$ 150$.

\footnotetext{
${ }^{28}$ Gustman and Steinmeier (2002b) conduct a similar exercise within the context of their structural model of retirement behavior and obtain analogous results.

${ }^{29}$ Both policy changes are currently legislated to be phased in gradually over the next 20 years

${ }^{30}$ Specifically, the change lowers the return to work at ages $62-63$ from $6.67 \%$ to $5 \%$, does not affect the return to
} 
The bias resulting from excluding spillover effects is calculated as follows for each policy change. I first estimate the average retirement probability at each age pre-policy change and post-policy change for a "true" retirement model including the spouse's incentive variable. Starting with a sample of 100 men in the labor force at age 50, I apply the pre- and post-policy change retirement probabilities by age to generate two survival functions; the difference between them is the cumulative effect of the policy change on the probability of being in the labor force at a particular age. I then repeat this exercise for a "naïve" retirement model excluding the spouse's incentive variable. The percent difference between the cumulative effect of the policy change calculated using the "true" and "naïve" models is the estimate of the bias resulting from excluding spillover effects.

The results of this analysis are presented in Table 6 for the OV model. ${ }^{31}$ Both policy changes are found to decrease the probability of retirement: using the "true" model, the probability of being in the labor force at age 65 is 1.0 percentage points lower with the NRA reform and 1.5 percentage points lower with the DRC reform. The "naïve" model excluding spillover effects is found to underestimate the effect of the policy change relative to the "true" model including spillover effects. At age 65 , for example, the effect of the policy change is underestimated by $13 \%$ in the NRA reform and by $20 \%$ in the DRC reform.

The magnitude of the bias is significant but modest. One possible explanation for why the bias is not larger is that, while women's incentives have a strong influence on men's retirement decision, the effect of the policy changes on women's incentives is often modest, as discussed above. Nonetheless, these estimates suggest that analysts who aim to make accurate estimates of the effects of policy changes should incorporate spillover effects, as estimates 
excluding spillover effects are found to significantly underestimate the true effect of a policy change on labor force participation.

\section{Conclusion}

The large literature estimating reduced-form models of the effect of Social Security and pensions on retirement has neglected two important questions: the effect of women's retirement incentives on their own retirement decisions and the spillover effects of each spouse's incentives on the other spouse's retirement decision. This paper addresses these questions using a rich new data set, the Health and Retirement Study, and taking full advantage of recent insights in the literature on men's retirement regarding identification of retirement impacts and the importance of incorporating forward-looking incentive measures.

I have two major findings. First, I find that the response of women to their own incentive measures is virtually identical to the response of men: in increase of $\$ 1,000$ in own dynamic retirement incentives lowers the probability of retirement by $0.9 \%$ of baseline for men and by $1.3 \%$ of baseline for women. Second, I find that spillover effects from the wife are an important determinant of the husband's retirement: an increase of $\$ 1,000$ in the wife's dynamic incentives lowers the probability of the husband's retirement by $0.8 \%$ of baseline. I further find that spillover effects from the husband have small and statistically insignificant effects on the wife.

These findings run counter to the conventional wisdom and long-standing assumption in the traditional retirement literature that men's retirement is unaffected by their wives' characteristics, and indicate that joint modeling of couples' retirement decisions is appropriate. I suggest that a weaker complementarity of leisure effect for women may explain the lack of significance of the husband's spillover effects. As confirmatory evidence, I show that men are

reform, the estimates of bias from the PV model are larger but quite variable at different ages. 
slightly more likely to say that they enjoy spending their leisure time with their spouses and that a subset of women who would be expected to have a strong complementarity of leisure effect have a similar response to spillover effects as the full sample of men.

Omitting spillover effects from a model of men's retirement does not significantly bias estimates of the effect of the husband's retirement incentives on his retirement. However, simulations of the effect of changes in Social Security policy on men's retirement may still be biased, as they neglect to take into account the effect that the change in the wife's incentives will have on the husband's decision. Simulations of two policy changes suggest that omitting spillover effects leads to an underestimate of the effect of the policy on the probability of being in the labor force at age 65 of $13-20 \%$. This suggests that analysts who wish to make careful estimates of the effect of policy changes should estimate household models of retirement decision-making. 


\section{References}

Baker, Michael (1999). "The Retirement Behavior of Married Couples: Evidence from the Spouse's Allowance,” NBER Working Paper \#7138.

Blau, David M. (1998). "Labor Force Dynamics of Older Married Couples," Journal of Labor Economics 16(3): 595-629.

Board of Trustees of the Federal Old-Age and Survivors Insurance and Disability Insurance Trust Funds (1995). 1995 Annual Report. Washington, D.C: U.S. Government Printing Office.

Boskin, Michael J. and Michael D. Hurd (1978). "The Effect of Social Security on Early Retirement,” Journal of Public Economics 10:361-377.

Bound, John (1991). "Self-Reported vs. Objective Measures of Health in Retirement Models," Journal of Human Resources 26:106-138.

Burtless, Gary (1986). "Social Security, Unanticipated Benefit Increases, and the Timing of Retirement," Review of Economic Studies 53:781-805.

Burtless, Gary and Robert Moffitt (1984). "The Effect of Social Security Benefits on the Labor Supply of the Aged," in Retirement and Economic Behavior, H. Aaron and G. Burtless, eds. Washington: Brookings Institution, 135-175.

Campione, Wendy A. (1987). “The Married Woman's Retirement Decision: A Methodological Comparison," Journal of Gerontology 42(4): 381-386.

Clark, Robert L., Thomas Johnson, and Ann A. McDermed (1980). "Allocation of Time and Resources by Married Couples Approaching Retirement," Social Security Bulletin 43(4):3-16.

Coile, Courtney, Peter Diamond, Jonathan Gruber, and Alain Jousten (2002). "Delays in Claiming Social Security Benefits," Journal of Public Economics 84(3): 357-385.

Coile, Courtney and Jonathan Gruber (2001). "Social Security Incentives for Retirement," in Themes in the Economics of Aging, David A. Wise, ed. Chicago: University of Chicago Press.

Coile, Courtney and Jonathan Gruber (2000). "Social Security and Retirement," National Bureau of Economic Research Working Paper \#7830.

Costa, Dora L. (1997). The Evolution of Retirement. Chicago: University of Chicago Press.

Desmet, Raphael, Jean-Marie Lozachmeur, and Sergio Perelman (2002). "An Analysis of Joint Retirement in Belgium," mimeo, University of Liege. 
Diamond, Peter and Jonathan Gruber (1998). "Social Security and Retirement in the United States," in Social Security and Retirement around the World, Jonathan Gruber and David A. Wise, eds. Chicago: University of Chicago Press.

Diamond, Peter and Jerry Hausman (1984). "Retirement and Unemployment Behavior of Older Men," in Retirement and Economic Behavior, H. Aaron and G. Burtless, eds. Washington: Brookings Institution.

Fields, Gary S. and Olivia S. Mitchell (1984). "Economic Determinants of the Optimal Retirement Age: An Empirical Investigation,” Journal of Human Resources 19(2): 245-262.

Gustman, Alan L. and Thomas L. Steinmeier (2002a). "The Social Security Early Entitlement Age in a Structural Model of Retirement and Wealth," National Bureau of Economic Research Working Paper \#9183.

Gustman, Alan L. and Thomas L. Steinmeier (2002b). "Social Security, Pensions, and Retirement Behavior Within the Family," National Bureau of Economic Research Working Paper \#8772.

Gustman, Alan L. and Thomas L. Steinmeier (2000). "Retirement in a Family Context: A Structural Model," Journal of Labor Economics 18(3): 503-545.

Gustman, Alan L. and Thomas L. Steinmeier (1985). "The 1983 Social Security Reforms and Labor Supply Adjustments of Older Individuals in the Long Run," Journal of Labor Economics 3(2): 237-253.

Harris, Amy Redher (2001). "Modeling Retirement Behavior: A Test of the Optional Value Model Using the Health and Retirement Study," unpublished manuscript, Congressional Budget Office.

Haider, Steven and Gary Solon (1999). "Nonrandom Selection in the HRS Social Security Earnings Sample," mimeo.

Hausman, Jerry A. and David A. Wise (1985). "Social Security, Health Status, and Retirement," in Pensions, Labor, and Individual Choice, David A. Wise, ed. Chicago: University of Chicago Press, 159-191.

Henretta, John C. and Angela M. O'Rand (1980). "Labor-Force Participation of Older Married Women," Social Security Bulletin 43(8):10-16.

Hurd, Michael D. (1990). "The Joint Retirement Decisions of Husbands and Wives," in Issues in the Economics of Aging, David A. Wise (ed.). Chicago: University of Chicago Press.

Hurd, Michael and Michael Boskin (1984). "The Effect of Social Security on Retirement in the Early 1970s,” Quarterly Journal of Economics 99:767-790. 
Johnson, Richard W. and Melissa M. Favreault (2001). "Retiring Together or Working Alone: The Impact of Spousal Employment and Disability on Retirement Decisions," mimeo, the Urban Institute.

Krueger, Alan B. and Jorn-Steffan Pischke (1992). "The Effect of Social Security on Labor Supply: A Cohort Analysis of the Notch Generation," Journal of Labor Economics 10(4): 412 437.

Lumsdaine, Robin and David Wise (1994). "Aging and Labor Force Participation," in Aging in the United States and Japan: Economic Trends, Y. Noguchi and D. Wise, eds. Chicago: University of Chicago Press.

Maestas, Nicole (2001). "Labor, Love, \& Leisure: Complementarity and the Timing of Retirement by Working Couples," mimeo, University of California at Berkeley.

McBride, Timothy D. (1988). "Women's Retirement Behavior: Implications for Future Policy," paper presented at American Economic Association Meetings.

McCarty, Therese A. (1990). "The Effect of Social Security on Married Women's Labor Force Participation," National Tax Journal 43(1):95-110.

Moen, Phyllis, J. E. Kim, and H. Hofmeister (2001). "Couples' Work/Retirement Transitions, Gender, and Marital Quality,” Social Psychology Quarterly 64: 55-71.

Panis, Constantijn, et. al. (2002). "The Effects of Changing Social Security Administration's Early Entitlement Age and the Normal Entitlement Age," unpublished paper prepared for the Social Security Administration.

Pozzebon, Silvana and Olivia S. Mitchell (1989). "Married Women's Retirement Behavior," Journal of Population Economics 2(1):39-53.

Quinn, Joseph F. (1999). "Has the Early Retirement Trend Reversed?" Boston College Working Papers in Economics \#424.

Ruhm, Christopher (1990). “Bridge Jobs and Partial Retirement," Journal of Labor Economics 8(4): 482-501.

Samwick, Andrew A. (1998). "New Evidence on Pensions, Social Security, and the Timing of Retirement," Journal of Public Economics 70(2): 207-236.

Social Security Administration (2002). "Income of the Aged Chartbook, 2000." Washington, D.C.

Stock, James H. and David A. Wise (1990a). "Pensions, the Option Value of Work, and Retirement," Econometrica 58(5):1151-1180. 
Stock, James H. and David A. Wise (1990b). "The Pension Inducement to Retire: An Option Value Analysis," Issues in the Economics of Aging, David A. Wise, ed. Chicago: University of Chicago Press, 205-229.

Vistnes, Jessica (1994). “An Empirical Analysis of Married Women's Retirement Decisions," National Tax Journal 47(1):135-155.

U.S. Department of Labor, Bureau of Labor Statistics (1988). Labor Force Statistics Derived from the CPS, 1948-1987. Washington: General Printing Office.

Weaver, David A. (1994). "The Work and Retirement Decisions of Older Women: A Literature Review," Social Security Bulletin 57(1):3-24. 
Table 1:

Summary Statistics

\begin{tabular}{|c|c|c|c|c|}
\hline \multirow[t]{2}{*}{ Variable } & \multicolumn{2}{|c|}{ Men } & \multicolumn{2}{|c|}{ Women } \\
\hline & Mean & $\begin{array}{l}\text { Standard } \\
\text { Deviation }\end{array}$ & Mean & $\begin{array}{l}\text { Standard } \\
\text { Deviation }\end{array}$ \\
\hline Retire This Year & 0.047 & 0.212 & 0.041 & 199.000 \\
\hline Accrual & 1,698 & 8,066 & 1,279 & 4,418 \\
\hline Peak Value & 14,766 & 26,427 & 11,541 & 27,180 \\
\hline Option Value & 13,690 & 9,372 & 8,274 & 7,264 \\
\hline PDV & 230,651 & 176,561 & 230,651 & 176,561 \\
\hline Age & 57.1 & 4.0 & 54.6 & 3.6 \\
\hline Age Difference & 2.5 & 3.5 & -- & -- \\
\hline Black & 0.087 & 0.282 & 0.084 & 0.278 \\
\hline Other Nonwhite & 0.051 & 0.221 & 0.060 & 0.238 \\
\hline Educ: $<12$ yrs & 0.187 & 0.390 & 0.132 & 0.338 \\
\hline Educ: 12 yrs & 0.377 & 0.485 & 0.480 & 0.500 \\
\hline Educ: $13-15$ yrs & 0.140 & 0.347 & 0.174 & 0.379 \\
\hline Earnings & 30,979 & 17,178 & 16,602 & 12,857 \\
\hline AIME & 2,110 & 767 & 775 & 576 \\
\hline Experience & 38.3 & 5.1 & 36.0 & 4.3 \\
\hline Job tenure & 16.9 & 12.3 & 11.6 & 9.4 \\
\hline Missing job tenure & 0.067 & 0.250 & 0.099 & 0.299 \\
\hline Number of Obs & 6,204 & & 6,204 & \\
\hline
\end{tabular}


Table 2:

Retirement Probits

Dependent Variable $=$ Husband's Retirement

\begin{tabular}{|c|c|c|c|c|c|c|c|c|c|}
\hline \multirow[t]{2}{*}{ Variable } & \multicolumn{9}{|c|}{ Specification } \\
\hline & (ACC1) & (ACC2) & (ACC3) & (PV1) & (PV2) & (PV3) & (OV1) & (OV2) & (OV3) \\
\hline Own ACC & $\begin{array}{c}-0.785 \\
(0.473) \\
{[-.00054]}\end{array}$ & $\begin{array}{c}-0.688 \\
(0.496) \\
{[-.00045]}\end{array}$ & $\begin{array}{c}-0.711 \\
(0.524) \\
{[-.00044]}\end{array}$ & & & & & & \\
\hline Own PV & & & & $\begin{array}{c}-0.697 \\
(0.215) \\
{[-.00046]}\end{array}$ & $\begin{array}{c}-0.639 \\
(0.220) \\
{[-.00040]}\end{array}$ & $\begin{array}{c}-0.734 \\
(0.227) \\
{[-.00042]}\end{array}$ & & & \\
\hline Own OV & & & & & & & $\begin{array}{l}-0.143 \\
(0.047)\end{array}$ & $\begin{array}{l}-0.309 \\
(0.077)\end{array}$ & $\begin{array}{c}-0.338 \\
(0.094)\end{array}$ \\
\hline Spouse ACC & $\begin{array}{c}-1.264 \\
(0.666) \\
{[-.00087]}\end{array}$ & $\begin{array}{c}-1.698 \\
(0.710) \\
{[-.00110]}\end{array}$ & $\begin{array}{c}-2.653 \\
(0.883) \\
{[-.00162]}\end{array}$ & & & & & & \\
\hline Spouse PV & & & & $\begin{array}{c}-0.505 \\
(0.172) \\
{[-.00033]}\end{array}$ & $\begin{array}{c}-0.598 \\
(0.191) \\
{[-.00038]}\end{array}$ & $\begin{array}{c}-0.934 \\
(0.215) \\
{[-.00053]}\end{array}$ & & & \\
\hline Spouse OV & & & & & & & $\begin{array}{l}-0.091 \\
(0.052)\end{array}$ & $\begin{array}{l}-0.250 \\
(0.086)\end{array}$ & $\begin{array}{c}-0.368 \\
(0.104)\end{array}$ \\
\hline PDV & $\begin{array}{c}0.077 \\
(0.022) \\
{[.00054]}\end{array}$ & $\begin{array}{c}0.065 \\
(0.024) \\
{[.00043]}\end{array}$ & $\begin{array}{c}0.085 \\
(0.027) \\
{[.00053]}\end{array}$ & $\begin{array}{c}0.091 \\
(0.023) \\
{[.00061]}\end{array}$ & $\begin{array}{c}0.073 \\
(0.025) \\
{[.00047]}\end{array}$ & $\begin{array}{c}0.097 \\
(0.028) \\
{[.00056]}\end{array}$ & $\begin{array}{c}0.068 \\
(0.021) \\
{[.00047]}\end{array}$ & $\begin{array}{c}0.013 \\
(0.025) \\
{[.00008]}\end{array}$ & $\begin{array}{c}0.018 \\
(0.031) \\
{[.00011]}\end{array}$ \\
\hline Demos & Yes & Yes & Yes & Yes & Yes & Yes & Yes & Yes & Yes \\
\hline Earn`4,AIME^4 $^{\wedge}$ & No & Yes & Yes & No & Yes & Yes & No & Yes & Yes \\
\hline Interactions & No & No & Yes & No & No & Yes & No & No & Yes \\
\hline Number of Obs & 5,632 & 5,632 & 4,327 & 5,632 & 5,632 & 4,327 & 5,632 & 5,632 & 4,327 \\
\hline
\end{tabular}


Table 3:

Retirement Probits

Dependent Variable $=$ Wife's Retirement

\begin{tabular}{|c|c|c|c|c|c|c|c|c|c|}
\hline \multirow[t]{2}{*}{ Variable } & \multicolumn{9}{|c|}{ Specification } \\
\hline & (ACC1) & (ACC2) & (ACC3) & (PV1) & (PV2) & (PV3) & (OV1) & (OV2) & (OV3) \\
\hline Own ACC & $\begin{array}{c}-0.734 \\
(0.680) \\
{[-.00043]}\end{array}$ & $\begin{array}{c}-0.500 \\
(0.649) \\
{[-.00027]}\end{array}$ & $\begin{array}{c}-0.893 \\
(0.709) \\
{[-.00040]}\end{array}$ & & & & & & \\
\hline Own PV & & & & $\begin{array}{c}-1.099 \\
(0.283) \\
{[-.00060]}\end{array}$ & $\begin{array}{c}-1.080 \\
(0.278) \\
{[-.00054]}\end{array}$ & $\begin{array}{c}-1.285 \\
(0.323) \\
{[-.00052]}\end{array}$ & & & \\
\hline Own OV & & & & & & & $\begin{array}{c}-0.227 \\
(0.062)\end{array}$ & $\begin{array}{c}-0.433 \\
(0.099)\end{array}$ & $\begin{array}{c}-0.514 \\
(0.112)\end{array}$ \\
\hline Spouse ACC & $\begin{array}{c}0.339 \\
(0.332) \\
{[.00020]}\end{array}$ & $\begin{array}{c}0.224 \\
(0.355) \\
{[.00012]}\end{array}$ & $\begin{array}{c}0.265 \\
(0.361) \\
{[.00012]}\end{array}$ & & & & & & \\
\hline Spouse PV & & & & $\begin{array}{c}0.014 \\
(0.138) \\
{[7.67 \mathrm{e}-06]}\end{array}$ & $\begin{array}{c}-0.058 \\
(0.145) \\
{[-.00003]}\end{array}$ & $\begin{array}{c}0.015 \\
(0.158) \\
{[6.12 \mathrm{e}-06]}\end{array}$ & & & \\
\hline Spouse OV & & & & & & & $\begin{array}{c}0.123 \\
(0.048)\end{array}$ & $\begin{array}{c}0.032 \\
(0.082)\end{array}$ & $\begin{array}{c}0.144 \\
(0.100)\end{array}$ \\
\hline PDV & $\begin{array}{c}0.106 \\
(0.022) \\
{[.00063]}\end{array}$ & $\begin{array}{c}0.081 \\
(0.023) \\
{[.00044]}\end{array}$ & $\begin{array}{c}0.119 \\
(0.028) \\
{[.00055]}\end{array}$ & $\begin{array}{c}0.120 \\
(0.023) \\
{[.00066]}\end{array}$ & $\begin{array}{c}0.095 \\
(0.024) \\
{[.00049]}\end{array}$ & $\begin{array}{c}0.138 \\
(0.030) \\
{[.00058]}\end{array}$ & $\begin{array}{c}0.113 \\
(0.023) \\
{[.00063]}\end{array}$ & $\begin{array}{c}0.065 \\
(0.029) \\
{[.00034]}\end{array}$ & $\begin{array}{c}0.119 \\
(0.035) \\
{[.00051]}\end{array}$ \\
\hline Demos & Yes & Yes & Yes & Yes & Yes & Yes & Yes & Yes & Yes \\
\hline $\operatorname{Earn}^{\wedge} 4, \mathrm{AIME}^{\wedge} 4$ & No & Yes & Yes & No & Yes & Yes & No & Yes & Yes \\
\hline Interactions & No & No & Yes & No & No & Yes & No & No & Yes \\
\hline Number of Obs & 5,639 & 5,639 & 4,482 & 5,639 & 5,639 & 4,482 & 5,639 & 5,639 & 4,482 \\
\hline
\end{tabular}


Table 4:

Retirement Expectations

Question

Men

Women

Time spent together with spouse is: extremely enjoyable

$32.9 \% \quad 27.0 \%$

Like to spend time doing things: together with spouse

$52.4 \% \quad 49.5 \%$

Look forward to retirement only if spouse can retire too: strongly agree/agree

$62.1 \%$

$59.6 \%$

Importance of potentially good things about retirement

Being your own boss: very important

$41.4 \% \quad 39.9 \%$

Lack of pressure: very important

$45.6 \% \quad 56.8 \%$

Being able to take it easy: very important

$39.7 \%$

$44.1 \%$

Having more time with spouse: very important

$61.2 \%$

$59.9 \%$

Spending more time with children: very important

$33.4 \%$

$42.0 \%$

Spending more time on hobbies or sports: very important

$29.7 \%$

$28.7 \%$

Having more time for volunteer work: very important

$13.3 \%$

$16.9 \%$

Having the chance to travel: very important

$46.9 \%$

$47.9 \%$

Note:

1) Tabulations are answers to 1992 survey for subset of sample in which neither spouse retires pre- 1992 . 
Table 5:

Probit Models with Complementarity of Leisure

\begin{tabular}{|c|c|c|c|c|}
\hline \multirow[t]{2}{*}{ Variable } & \multicolumn{4}{|c|}{ Specification } \\
\hline & No CL & Defn 1 & Defn 2 & Defn 3 \\
\hline \multicolumn{5}{|c|}{ Dependent Variable: Wife's Retirement } \\
\hline Spouse PV & $\begin{array}{r}0.064 \\
(0.195)\end{array}$ & $\begin{array}{r}0.330 \\
(0.219)\end{array}$ & $\begin{array}{r}0.451 \\
(0.225)\end{array}$ & $\begin{array}{r}0.359 \\
(0.225)\end{array}$ \\
\hline Spouse $\mathrm{PV} * \mathrm{CL}$ & & $\begin{array}{r}-0.790 \\
(0.431)\end{array}$ & $\begin{array}{r}-1.341 \\
(0.428)\end{array}$ & $\begin{array}{r}-1.046 \\
(0.454)\end{array}$ \\
\hline Comp of Leisure & & $\begin{array}{r}0.350 \\
(0.122)\end{array}$ & $\begin{array}{r}0.426 \\
(0.130)\end{array}$ & $\begin{array}{r}0.312 \\
(0.130)\end{array}$ \\
\hline Own PV & $\begin{array}{r}-0.636 \\
(0.265)\end{array}$ & $\begin{array}{r}-0.607 \\
(0.273)\end{array}$ & $\begin{array}{r}-0.490 \\
(0.280)\end{array}$ & $\begin{array}{r}-0.448 \\
(0.270)\end{array}$ \\
\hline PDV & $\begin{array}{r}0.105 \\
(0.026)\end{array}$ & $\begin{array}{r}0.103 \\
(0.026)\end{array}$ & $\begin{array}{r}0.102 \\
(0.031)\end{array}$ & $\begin{array}{r}0.102 \\
(0.031)\end{array}$ \\
\hline Number of Obs & 4,391 & 4,371 & 3,775 & 3,775 \\
\hline \multicolumn{5}{|c|}{ Dependent Variable: Husband's Retirement } \\
\hline Spouse PV & $\begin{array}{c}-0.619 \\
(0.228)\end{array}$ & $\begin{array}{r}-0.355 \\
(0.230)\end{array}$ & $\begin{array}{r}-0.223 \\
(0.267)\end{array}$ & $\begin{array}{l}-0.296 \\
(0.249)\end{array}$ \\
\hline $\mathrm{Sp} \mathrm{PV} * \mathrm{CL}$ & & $\begin{array}{r}-1.327 \\
(0.577)\end{array}$ & $\begin{array}{r}-1.040 \\
(0.494)\end{array}$ & $\begin{array}{r}-1.400 \\
(0.639)\end{array}$ \\
\hline Comp of Leisure & & $\begin{array}{r}0.365 \\
(0.100)\end{array}$ & $\begin{array}{r}0.360 \\
(0.111)\end{array}$ & $\begin{array}{r}0.470 \\
(0.123)\end{array}$ \\
\hline Own PV & $\begin{array}{c}-0.329 \\
(0.241)\end{array}$ & $\begin{array}{r}-0.254 \\
(0.248)\end{array}$ & $\begin{array}{r}-0.118 \\
(0.279)\end{array}$ & $\begin{array}{r}-0.110 \\
(0.281)\end{array}$ \\
\hline PDV & $\begin{array}{r}0.072 \\
(0.024)\end{array}$ & $\begin{array}{r}0.046 \\
(0.026)\end{array}$ & $\begin{array}{r}0.071 \\
(0.029)\end{array}$ & $\begin{array}{r}0.067 \\
(0.029)\end{array}$ \\
\hline Number of Obs & 4,522 & 4,318 & 3,831 & 3,831 \\
\hline
\end{tabular}

Note: Probits include demographic variables and quartics in earnings and AIME. 
Table 6:

Predicted Effect of Policy Changes on Men's Retirement

\begin{tabular}{|c|c|c|c|c|c|c|c|}
\hline \multirow[t]{3}{*}{ Age } & \multicolumn{6}{|c|}{ Survival Function (\% in LF) } & \multirow{3}{*}{$\begin{array}{l}\text { \% Diff } \\
\text { in Effect } \\
\text { of Policy } \\
\text { Naïve-True }\end{array}$} \\
\hline & \multicolumn{3}{|c|}{ "True" Model } & \multicolumn{3}{|c|}{ "Naive" Model } & \\
\hline & Pre-Policy & Post-Policy & $\begin{array}{c}\text { Effect of } \\
\text { Policy }\end{array}$ & Pre-Policy & Post-Policy & $\begin{array}{c}\text { Effect } \\
\text { of Policy }\end{array}$ & \\
\hline \multicolumn{8}{|c|}{ NRA Policy Change, OV Model } \\
\hline 50 & 98.226 & 98.250 & 0.024 & 98.241 & 98.259 & 0.018 & $-23.8 \%$ \\
\hline 51 & 94.627 & 94.688 & 0.061 & 94.625 & 94.674 & 0.049 & $-18.5 \%$ \\
\hline 52 & 92.391 & 92.475 & 0.084 & 92.389 & 92.459 & 0.070 & $-17.3 \%$ \\
\hline 53 & 90.287 & 90.396 & 0.109 & 90.283 & 90.375 & 0.092 & $-15.9 \%$ \\
\hline 54 & 88.750 & 88.878 & 0.128 & 88.745 & 88.854 & 0.109 & $-14.9 \%$ \\
\hline 55 & 84.697 & 84.871 & 0.173 & 84.716 & 84.865 & 0.149 & $-13.9 \%$ \\
\hline 56 & 82.776 & 82.976 & 0.200 & 82.794 & 82.967 & 0.173 & $-13.5 \%$ \\
\hline 57 & 79.852 & 80.095 & 0.243 & 79.848 & 80.060 & 0.211 & $-13.2 \%$ \\
\hline 58 & 76.962 & 77.253 & 0.291 & 76.951 & 77.205 & 0.254 & $-12.8 \%$ \\
\hline 59 & 74.329 & 74.666 & 0.336 & 74.306 & 74.599 & 0.294 & $-12.7 \%$ \\
\hline 60 & 71.067 & 71.464 & 0.397 & 71.064 & 71.411 & 0.347 & $-12.5 \%$ \\
\hline 61 & 64.857 & 65.353 & 0.496 & 64.856 & 65.291 & 0.435 & $-12.2 \%$ \\
\hline 62 & 53.540 & 54.166 & 0.626 & 53.571 & 54.118 & 0.547 & $-12.5 \%$ \\
\hline 63 & 45.896 & 46.668 & 0.771 & 45.900 & 46.571 & 0.671 & $-13.1 \%$ \\
\hline 64 & 40.194 & 41.109 & 0.915 & 40.207 & 41.003 & 0.796 & $-13.0 \%$ \\
\hline 65 & 34.347 & 35.364 & 1.017 & 34.372 & 35.254 & 0.882 & $-13.2 \%$ \\
\hline 66 & 28.639 & 29.637 & 0.998 & 28.650 & 29.510 & 0.860 & $-13.8 \%$ \\
\hline 67 & 26.302 & 27.260 & 0.958 & 26.299 & 27.118 & 0.819 & $-14.5 \%$ \\
\hline 68 & 22.041 & 22.896 & 0.855 & 22.049 & 22.771 & 0.722 & $-15.6 \%$ \\
\hline 69 & 19.677 & 20.463 & 0.786 & 19.670 & 20.327 & 0.657 & $-16.4 \%$ \\
\hline \multicolumn{8}{|c|}{ DRC Policy Change, OV Model } \\
\hline 50 & 98.226 & 98.263 & 0.037 & 98.241 & 98.258 & 0.017 & $-53.2 \%$ \\
\hline 51 & 94.627 & 94.725 & 0.098 & 94.625 & 94.676 & 0.051 & $-47.8 \%$ \\
\hline 52 & 92.391 & 92.530 & 0.139 & 92.389 & 92.464 & 0.075 & $-45.8 \%$ \\
\hline 53 & 90.287 & 90.465 & 0.178 & 90.283 & 90.384 & 0.101 & $-43.1 \%$ \\
\hline 54 & 88.750 & 88.959 & 0.209 & 88.745 & 88.869 & 0.124 & $-40.9 \%$ \\
\hline 55 & 84.697 & 84.984 & 0.286 & 84.716 & 84.898 & 0.182 & $-36.3 \%$ \\
\hline 56 & 82.776 & 83.111 & 0.335 & 82.794 & 83.014 & 0.220 & $-34.3 \%$ \\
\hline 57 & 79.852 & 80.264 & 0.412 & 79.848 & 80.130 & 0.281 & $-31.7 \%$ \\
\hline 58 & 76.962 & 77.459 & 0.497 & 76.951 & 77.299 & 0.348 & $-30.0 \%$ \\
\hline 59 & 74.329 & 74.912 & 0.583 & 74.306 & 74.721 & 0.415 & $-28.8 \%$ \\
\hline 60 & 71.067 & 71.763 & 0.695 & 71.064 & 71.569 & 0.505 & $-27.4 \%$ \\
\hline 61 & 64.857 & 65.744 & 0.887 & 64.856 & 65.515 & 0.659 & $-25.7 \%$ \\
\hline 62 & 53.540 & 54.700 & 1.160 & 53.571 & 54.459 & 0.888 & $-23.4 \%$ \\
\hline 63 & 45.896 & 47.265 & 1.368 & 45.900 & 46.965 & 1.065 & $-22.2 \%$ \\
\hline 64 & 40.194 & 41.693 & 1.499 & 40.207 & 41.388 & 1.180 & $-21.3 \%$ \\
\hline 65 & 34.347 & 35.975 & 1.628 & 34.372 & 35.667 & 1.295 & $-20.4 \%$ \\
\hline 66 & 28.639 & 30.229 & 1.590 & 28.650 & 29.915 & 1.264 & $-20.5 \%$ \\
\hline 67 & 26.302 & 27.832 & 1.530 & 26.299 & 27.513 & 1.215 & $-20.6 \%$ \\
\hline 68 & 22.041 & 23.354 & 1.313 & 22.049 & 23.088 & 1.039 & $-20.9 \%$ \\
\hline 69 & 19.677 & 20.859 & 1.181 & 19.670 & 20.587 & 0.917 & $-22.4 \%$ \\
\hline
\end{tabular}




\section{Figure 1: Labor Force Participation Rate,}

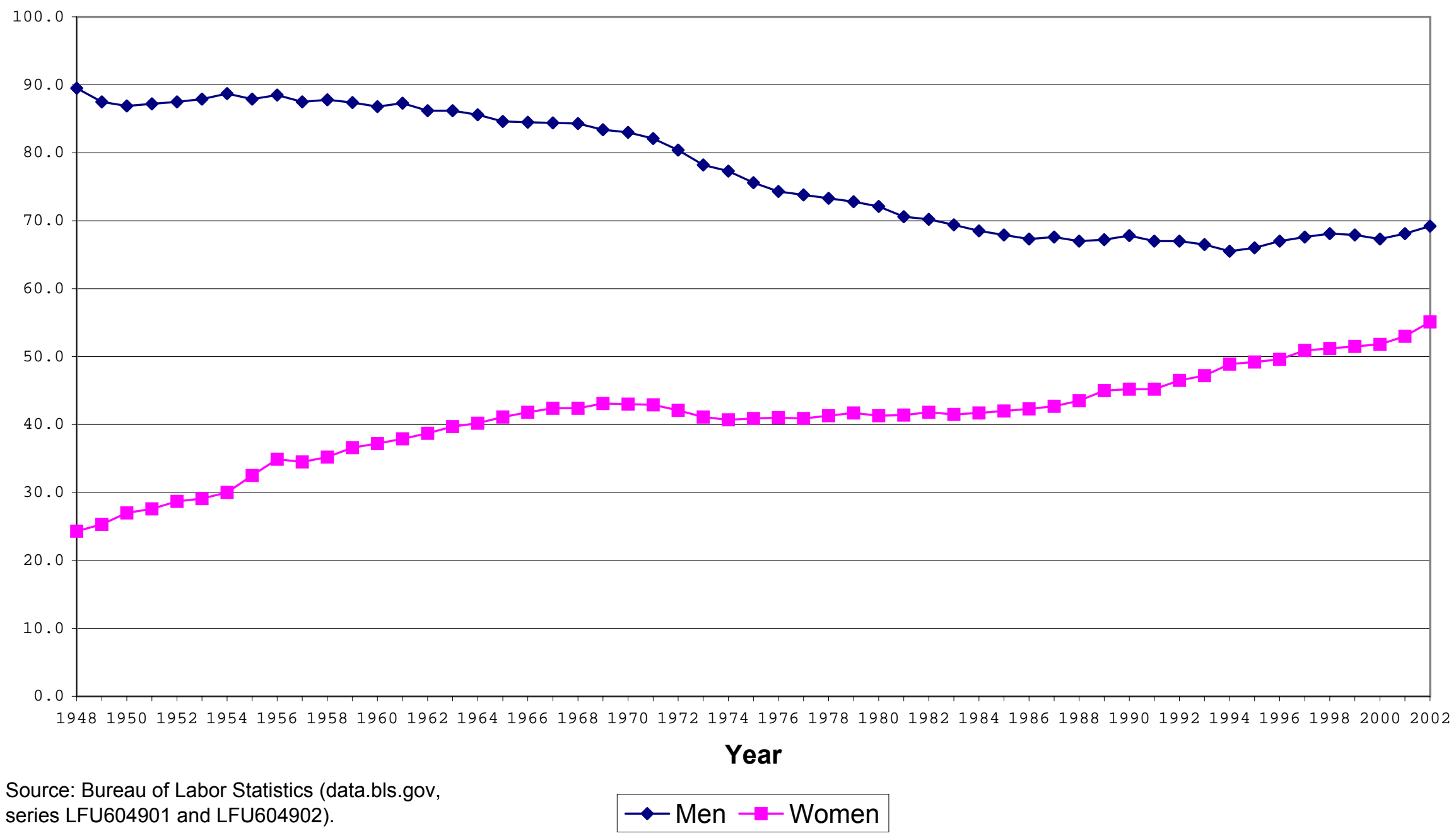


Figure 2: Retirement Hazard of Married Men and Women in HRS

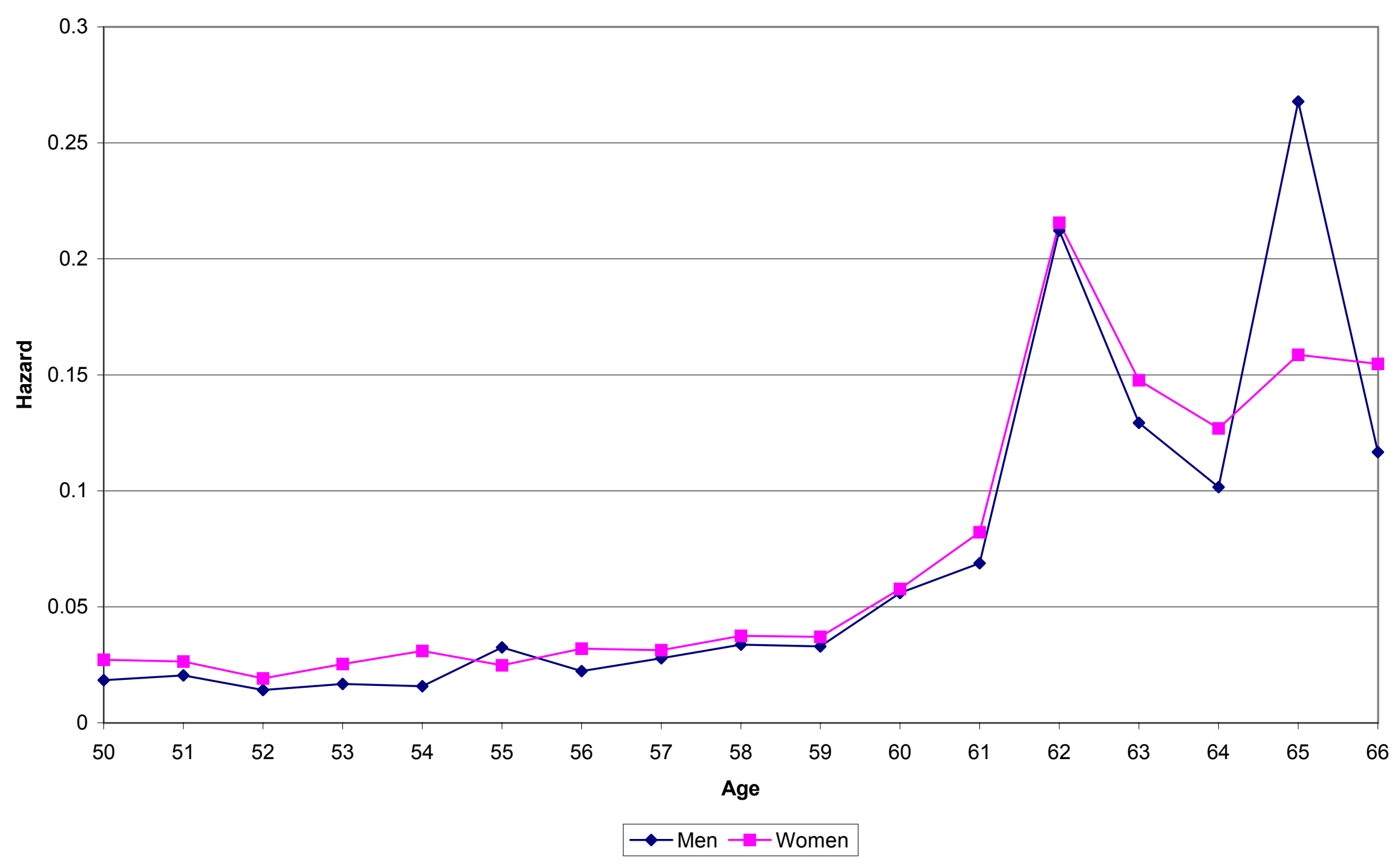

